\title{
Ozonesonde profiles from the West Pacific Warm Pool: measurements and validation
}

\author{
R. Newton ${ }^{1}$, G. Vaughan ${ }^{1}$, H. M. A. Ricketts ${ }^{1}$, L. L. Pan ${ }^{2}$, A. J. Weinheimer ${ }^{2}$, and C. Chemel ${ }^{3}$ \\ ${ }^{1}$ National Centre for Atmospheric Science, The University of Manchester, Manchester, UK \\ ${ }^{2}$ National Center for Atmospheric Research, Boulder, Colorado, USA \\ ${ }^{3}$ National Centre for Atmospheric Science, University of Hertfordshire, Hatfield, UK \\ Correspondence to: G. Vaughan (geraint.vaughan@manchester.ac.uk)
}

Received: 20 May 2015 - Published in Atmos. Chem. Phys. Discuss.: 18 June 2015

Revised: 20 October 2015 - Accepted: 12 January 2016 - Published: 20 January 2016

\begin{abstract}
We present a series of ozonesonde profiles measured from Manus Island, Papua New Guinea, during February 2014, with new insights on the calibration of ozonesondes for measurements in the tropical troposphere. The experiment formed a part of a wider airborne campaign involving three aircraft based in Guam, to characterise the atmospheric composition above the tropical West Pacific in unprecedented detail. Thirty-nine ozonesondes were launched between 2 and 25 February of which 34 gave good ozone profiles. Particular attention was paid to evaluating the background current of the ozonesondes, as this can amount to half the measured signal in the tropical tropopause layer (TTL). An unexpected contamination event affected the measurements and required a departure from standard operating procedures for the ozonesondes. The most significant departure was not exposing the sondes to ozone during preparation, which meant that the background current remained stable before launch. Comparison with aircraft measurements allows validation of the measured ozone profiles and confirms that for well-characterized sondes (background current $\sim 50 \mathrm{nA}$ ) a constant background current could be assumed throughout the profile, equal to the minimum value measured during preparation just before launch. From this set of 34 ozonesondes, the minimum reproducible ozone concentration measured in the TTL was 12-13 ppbv; no examples of ozone concentrations $<5 \mathrm{ppbv}$, as reported by other recent papers, were measured. The lowest ozone concentrations coincided with outflow from extensive deep convection to the east of Manus, consistent with uplift of ozone-poor air from the boundary layer. However, these minima were lower
\end{abstract}

than the ozone concentration measured through most of the boundary layer, and were matched only by measurements at the surface in Manus.

\section{Introduction}

The Tropical Tropopause Layer (TTL) is the region of the tropical atmosphere between the top of the main convective outflow and the base of the stratosphere (approximately 13$17 \mathrm{~km}$ altitude) (Holton et al., 1995; Highwood and Hoskins, 1998; Folkins et al., 1999; Gettelman and Forster, 2002; Fueglistaler et al., 2009; Ploeger et al., 2011; Pan et al., 2014). It is a transition layer between the convectively dominated mid-troposphere beneath and the statically stable (and convection-free) stratosphere above, with composition dependent both on convective uplift and large-scale transport. Since the TTL is the main source region for air entering the stratosphere in the Brewer-Dobson circulation, the concentrations of source gases within it determine the stratospheric burden of ozone-destroying radicals such as $\mathrm{Cl}_{x}$ and $\mathrm{Br}_{x}$. Furthermore, the temperature of the cold point determines the concentration of water vapour in the stratosphere, while clouds in the TTL, especially near the cold point, affect the radiation budget. The TTL is therefore a region of considerable importance both for global stratospheric chemistry and for climate.

The region of the tropics from the Maritime Continent to the International Date Line is known as the Tropical Warm Pool, where very warm sea surface temperatures 
$\left(>28^{\circ} \mathrm{C}\right.$ ) support widespread deep convection (Wang and Mehta, 2008). The tropopause is higher and colder here than in other regions of the tropics, especially in Northern Hemisphere winter, making this region of particular importance for the dehydration of air as it enters the stratosphere (Fueglistaler et al., 2009). The West Pacific region is also noted for very low ozone concentrations. Satellite measurements of total ozone show a zonal wave-one structure in the tropics with a maximum over the Atlantic sector and minimum over the West Pacific (Thompson, 2003; Takashima and Shiotani, 2007). This pattern is not restricted to the stratosphere: tropospheric ozone concentrations are also a minimum in the same region, generally attributed to photochemical destruction of ozone in the very clean marine boundary layer followed by rapid vertical mixing by deep convection (Thompson, 2003).

Folkins et al. (2002) noted that tropical ozone profiles typically exhibit an "S" shape with height, with a minimum concentration in the boundary layer (where ozone is destroyed photochemically), a maximum in the mid-troposphere due to long-range transport, and a further minimum at around $11 \mathrm{~km}$ before increasing into the stratosphere. They argued that this is consistent with the effect of deep convection lifting air from the boundary layer to the outflow region. Closer examination of this process however suggests a more complex explanation. Heyes et al. (2009) analysed a series of ozonesondes launched from Darwin, Australia as part of the ACTIVE campaign (Vaughan et al., 2008) and concluded that the lowest TTL concentrations of ozone occurred above the level of convective outflow. Back-trajectories suggested that the origin of this air lay to the north-east of Darwin, to the east and north-east of New Guinea. Uplift of air in large convective complexes over the warm ocean in this region was proposed as the source region for the lowest ozone concentrations measured over Darwin. This suggests that there may be preferred locations or "hot spots" for lifting material to the TTL.

A controversial question regarding ozone measurements in the TTL is whether the concentrations can fall to nearzero values $(<10 \mathrm{ppbv})$ in the outflow of deep convection. Ozonesonde observations during the CEPEX cruise over the central Pacific frequently measured ozone concentrations less than $10 \mathrm{ppbv}$, and occasionally close to zero in the TTL (Kley et al., 1996). The authors suggested that lifting of nearsurface air (where ozone is often strongly depleted in the tropics) essentially unmodified to the outflow of the convection could explain these observations, but they also pointed out that near-zero ozone in the TTL was encountered more frequently than near the surface during the cruise, and postulated that there may be a hitherto-unknown mechanism to destroy ozone in clouds. Model simulations by Lawrence et al. (1999) showed that minima in ozone concentration in the TTL over the West Pacific result from convective uplift, but could not replicate the very low ozone concentrations found by Kley et al. Such near-zero ozone values in ozonesonde profiles were also reported by Solomon et al. (2005) and Rex et al. (2014), again in the West Pacific region.

Doubts about the validity of these very low ozone concentrations were raised by Vömel and Diaz (2010), who examined in detail how the ozonesonde measurement is made. In particular they examined the background current - an interfering signal that must be allowed for when deriving ozone concentrations from the raw data. Vömel and Diaz (2010) pointed out that the ozonesondes in Kley et al. (1996) and Solomon et al. (2005) measuring the lowest TTL ozone concentrations also had the highest background current. A reexamination of the ozonesonde profiles of Heyes et al. (2009) shows that the same issue may have arisen there with the minimum value of $4 \mathrm{ppbv}$ occurring in a sonde with a higher background current than the others in that series (Sect. 3). We discuss the issue of the background current in detail in Sect. 2, but there is clearly uncertainty in the literature on the best way to account for it when calculating ozone profiles from the raw ozonesonde data. One of the aims of this paper is to shed light on this uncertainty.

We present a series of ozonesonde profiles measured from Manus Island, Papua New Guinea $\left(2.07^{\circ} \mathrm{S}, 147.4^{\circ} \mathrm{E}\right)$ during February 2014 as part of the CAST/CONTRAST/ATTREX (Coordinated Airborne Studies in the Tropics/Convective Transport of Active Species in the Tropics/Airborne Tropical Tropopause Experiment) campaign to investigate the composition of the atmosphere above the West Pacific Warm Pool. The campaign featured three aircraft based in Guam $\left(13.5^{\circ} \mathrm{N}, 144.8^{\circ} \mathrm{E}\right)$, to the north of the Warm Pool: the NASA Global Hawk, the NCAR Gulfstream V and the UK Natural Environment Research Council's BAe146 (Fig. 1). The ground campaign took place at the Atmospheric Radiation Measurement (ARM) site next to the airport on Manus, and comprised an ozonesonde campaign with supporting ground-level observations from a TECO-49C UV photometric ozone monitor, a Picarro G-2401 cavity ring-down spectrometer to measure $\mathrm{CO}_{2}, \mathrm{CH}_{4}$ and $\mathrm{CO}$, and a homebuilt gas chromatograph to measure halogenated compounds (Gostlow et al., 2010). Support with both logistics and meteorological data were provided by ARM and the Papua New Guinea Meteorological Service. The ground-based data set was collected between 1 and 25 February 2014, with 39 ozonesonde ascents ( 34 of which gave good data) between 2 and 25 February. As we show in this paper, overflights of the NCAR Gulfstream V provided an opportunity to validate ozonesonde measurements in the TTL during conditions of low ozone concentration.

A key result of the CONTRAST campaign, reported by Pan et al. (2015), is the bimodal distribution of free tropospheric ozone concentration measured over the tropical Western Pacific. Gulfstream V in situ measurements indicate that vertical mixing and uplift of near-surface air maintains a primary mode, narrowly distributed around $20 \mathrm{ppbv}$, from the surface to $15 \mathrm{~km}$. A secondary mode below $10 \mathrm{~km}$, broadly distributed around $60 \mathrm{ppbv}$, was identified as incursions of 


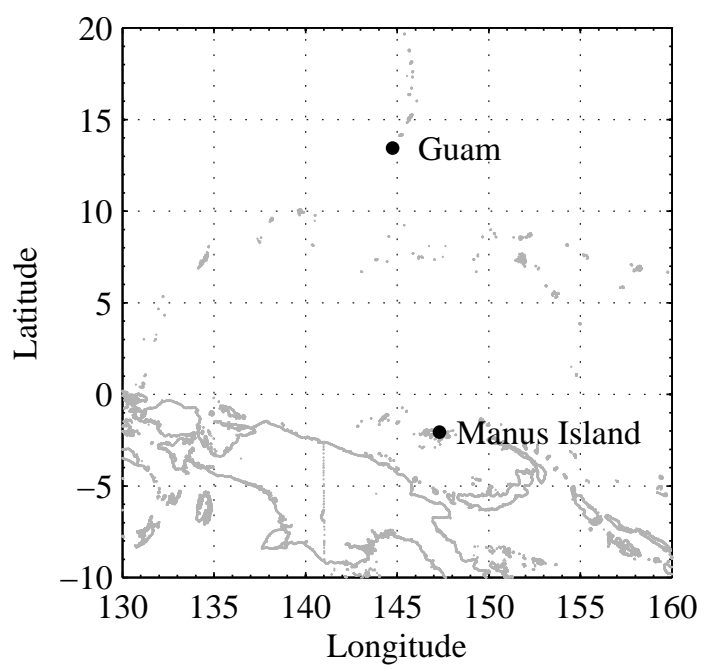

Figure 1. Map of the experimental area, with Manus and Guam labelled.

midlatitude air based on the low humidity and layered structure. The minimum ozone concentration measured during CONTRAST between 12 and $15 \mathrm{~km}$ was $13 \mathrm{ppbv}$, consistent with Vömel and Diaz (2010)'s contention that ozonesonde measurements of much lower concentrations are not reliable.

In Sect. 2, experimental details of the ozonesonde campaign are presented, including the procedure to correct for the background current. Section 3 presents the aircraft measurements used to validate the ozonesonde profiles. Section 4 presents a summary of the ozonesonde and ground-level ozone measurements, and the conclusions are in Sect. 5.

\section{Experimental details}

\subsection{The ozonesonde measurement technique}

The ozonesonde technique relies on an electrochemical reaction between ozone and potassium iodide (Eq. 1), followed by half-cell reactions in the anode (Eq. 2) and cathode (Eq. 3) (Komhyr, 1969).

$$
\begin{aligned}
& 2 \mathrm{KI}+\mathrm{O}_{3}+\mathrm{H}_{2} \mathrm{O} \rightarrow 2 \mathrm{KOH}+\mathrm{I}_{2}+\mathrm{O}_{2} \\
& 3 \mathrm{I}^{-} \rightarrow \mathrm{I}_{3}^{-}+2 e^{-} \\
& \mathrm{I}_{2}+2 e^{-} \rightarrow 2 \mathrm{I}^{-}
\end{aligned}
$$

The anode half-cell contains a saturated potassium iodide solution and the cathode an unsaturated KI solution; as the ozonesonde ascends, a teflon pump bubbles air through the cathode cell. The current produced is proportional to the flow of ozone through the cathode cell, with each ozone molecule assumed to generate two electrons (Komhyr, 1969). However, this is not the only reaction that produces a current within the ozonesonde: other reactants produce a residual background current (Thornton and Niazy, 1982), which in- creases the measured signal and which must be accounted for when calculating the ozone concentration.

The background current is of particular importance in the TTL where it can be a substantial fraction of the total current measured by the sonde. The best way to correct for the background current is the subject of much debate (e.g. Komhyr and Harris, 1971; Thornton and Niazy, 1982, 1983; Reid et al., 1996; Smit and Sträter, 2004; Smit et al., 2007), and the two main manufacturers of ozonesondes, Droplet Measurement Technologies and Science Pump Corporation, recommend two different methods: either a constant value measured before launch or a value that scales linearly with ambient pressure. The practice of using a pressure-dependent correction arises from early suggestions that the ozonesonde reacts with oxygen (Komhyr and Harris, 1971), but later studies ruled out this mechanism and suggested that the background current should be taken as constant with altitude, at least in the troposphere (Thornton and Niazy, 1982; Reid et al., 1996). However, Johnson et al. (2002) found that a background reaction with the phosphate buffers of a standard electrolyte solution did lead to a time dependence.

This confusion led Vömel and Diaz (2010) to examine in detail the issue of background current. In the normal preparation of an ozonesonde, the sonde is exposed to stratospheric concentrations of ozone to check that it is responding correctly. The background current is measured as the sonde is drawing in ozone-free air before and after exposure to ozone. Reid et al. (1996) recommended that the first of these measurements be adopted as the background current and removed (as a constant value) from current measurements in flight. However the standard procedure for ozonesonde preparation (Smit et al., 2007) uses a value measured $10 \mathrm{~min}$ after exposure to ozone. Vömel and Diaz (2010) found that the background current continues to decrease after exposure to ozone, even for periods of hours - suggesting that a value measured $10 \mathrm{~min}$ after exposure to ozone will be an overestimate by the time a sonde reaches the TTL, leading to an underestimate of the ambient ozone concentration when subtracted from the measured current. This decrease in background current is strongly dependent on the strength of the phosphate buffer concentration in the cell solution. Vömel and Diaz (2010) recommended the use of a background current $I_{\mathrm{bg}}=0.09 I+0.014 \mu \mathrm{A}$ for the $1 \% \mathrm{KI}$, full-buffer cathode cell solutions used in this paper, regardless of the measurements made during sonde preparation; the dependence of $I_{\mathrm{bg}}$ on the current $I$ suggesting that the assumption of two electrons per ozone molecule passing through the cathode cell is not correct. Reprocessing past soundings with this formula for background current was shown to remove all the cases of near-zero ozone - not surprising as the background current of $\sim 0.025 \mu \mathrm{A}$ that this gives in the TTL is well below the $0.065 \mu \mathrm{A}$ used for example in the original analysis of the CEPEX data. Independent verification of Vömel and Diaz (2010) has however not been performed to date, and we 
examine below the application of this recommendation to the Manus data set and the comparison with aircraft data.

It is clear from previous work that the background current is not a well-defined quantity, and that there is uncertainty on the best way to measure it and its possible variation during flight. This is acknowledged by the Global Atmospheric Watch (GAW) report on ozonesondes (Smit et al., 2013) which calls for more fundamental research on this topic. We now describe in detail the ozonesonde preparation method in Manus, which departed from GAW-standard procedures in a number of ways.

\subsection{Ozonesonde preparation}

The ozonesondes used here were EnSci Model Z sondes supplied by Droplet Measurement Technologies, coupled to Väisälä RS92G radiosondes which provided pressure, temperature, humidity and wind profiles. All were from the same batch of sondes supplied just before the campaign. The cathode solution comprised $1 \% \mathrm{KI}$ with $25 \mathrm{~g} \mathrm{~L}^{-1}$ of $\mathrm{KBr}$, $5 \mathrm{~g} \mathrm{~L}^{-1} \mathrm{Na}_{2} \mathrm{HPO}_{4} \cdot 12 \mathrm{H}_{2} \mathrm{O}$ and $1 \cdot 25 \mathrm{~g} \mathrm{~L}^{-1} \mathrm{NaH}_{2} \mathrm{PO}_{4} \cdot \mathrm{H}_{2} \mathrm{O}$ as buffers. Standard procedures for preparing ozonesondes follow a two-stage process aimed at reducing the background current to less than $50 \mathrm{nA}$ at the time of launch and measuring the sonde's pump flow rate. In this work the background current was obtained by drawing air into the sonde through a charcoal filter in an air-conditioned cabin where $\mathrm{RH}<50 \%$ at all times. The current was measured with a Keithley 6485 picoammeter, and the pump flow rate $F$ (in $\mathrm{mL} \mathrm{min}^{-1}$ ) with a Sensodyne Gilibrator unit. Repeated measurements of pump flow rate generally agree to $1-2 \%$. The ozone partial pressure $p_{\mathrm{O}_{3}}$ (in $\mathrm{mPa}$ ) was derived from the measured sonde current as

$p_{\mathrm{O}_{3}}=4.307 \times 10^{-4}\left(I-I_{\mathrm{bg}}\right) T_{\mathrm{box}}\left(\frac{6000}{F}\right)$,

where $T_{\text {box }}$ was measured by taping a thermistor to the inlet tube as it entered the ozonesonde pump. In this equation $I$ and $I_{\text {bg }}$ are both measured in $\mu \mathrm{A}$ and $T_{\text {box }}$ in K. A pump correction following Komhyr et al. (1995) was also applied to the data but this is negligible for the altitude range considered in this paper.

The ozonesonde preparation procedures normally involve, at different stages, purging the electrochemical cell and/or the pump with high concentrations of ozone, characterising the cell response to expected atmospheric concentrations of ozone and drawing ozone-free air through the cell. For this a Science Pump TSC01 ozone calibration unit was available. Normally, each ozonesonde would be first prepared 35 days before flight, in a four-step process: (i) passing high ozone through a new cell to remove organic traces; (ii) filling the anode and cathode cells and waiting for the current to fall to $0.5 \mu \mathrm{A}$ while drawing in ozone-free air; (iii) exposing the cell to atmospheric concentrations of ozone to verify its response; (iv) again drawing ozone-free air, measuring the time response of the cell and the background current after $\sim 10 \mathrm{~min}$. Then, on the day of flight, a second preparation would follow basically the same steps except that high ozone was only passed through the pump rather than the cathode cell. Standard ozonesonde procedures specify a change of solution once, at the beginning of the second preparation. We found in Manus, however, that repeated changes of solution were needed to reduce the background current to an acceptable value (the number of changes varied from sonde to sonde according to its requirements). The background current was measured both at the beginning of the second preparation and as the minimum value recorded by the Väisälä software after the sonde package was finally assembled (but before taking it out of the air-conditioned environment - in the humid tropical atmosphere outside the cabin the charcoal destruction filter does not work correctly).

The procedures used in Manus departed, as already mentioned, from the GAW recommendations. The most important deviation (a consequence of the malfunctioning calibration unit, see below) was that the majority of sondes were not exposed to ozone during preparation. This turns out to have been advantageous, as it avoided the decay in $I_{\text {bg }}$ reported by Vömel and Diaz (2010). Smit et al. (2007) report that the background current measured $10 \mathrm{~min}$ after exposure to ozone in the final preparation exceeded that measured before exposure to ozone by $34 \mathrm{nA}$ on average for a sample of five EnSci sondes. By contrast, for the uncontaminated sondes in Manus the average difference in $I_{\text {bg }}$ measured at the beginning and end of the final preparation was only $6 \mathrm{nA}$ (Fig. 2). Together with changes in solution to ensure that $I_{\mathrm{bg}}$ fell to around $50 \mathrm{nA}$, not exposing the cell to ozone resulted in a stable $I_{\mathrm{bg}}$ during preparation, lending confidence to the subsequent assumption that it remained constant during flight. We examine this assumption further in the next section.

Other departures from GAW recommendations were the following:

- The use of a $1 \%$ solution rather than the $0.5 \%$ which leads to an oversensitivity to ozone and a bias of $\sim+5 \%$ in ozone concentration (Smit et al., 2013).

- Measurement of $T_{\text {box }}$ rather than the pump temperature, leading to an underestimate of ozone by $\sim 3 \%$ since the pump temperature is higher by around $10{ }^{\circ} \mathrm{C}$ (Smit et al., 2013).

- Use of a charcoal filter to provide ozone-free air rather than an ozone-free gas supply. The effect of this is difficult to quantify, but will be most serious in a laboratory with humid air and measurable concentrations of ozone. In this case the relative humidity of cabin air was around $50 \%$, within the expected operational range of the filter. On occasion a sonde was allowed to sample laboratory air without the filter attached, but this made no difference to the measured current. This means either that the laboratory was essentially ozone-free or that the filter 


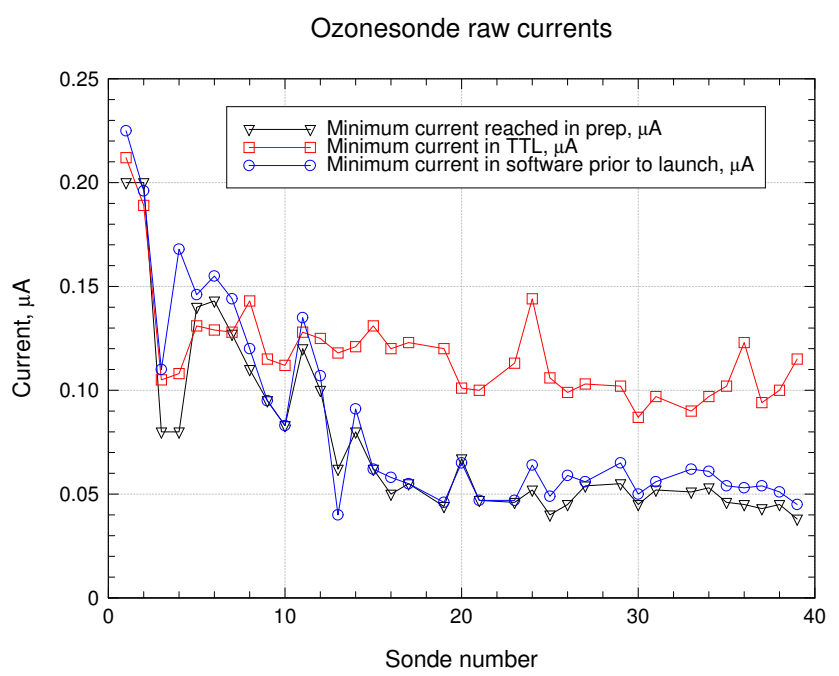

Figure 2. Values of background current measured at the beginning and end of the day-of-flight preparation (black and blue respectively) and the minimum current measured in the TTL during flight for the 34 successful ozonesondes.

was not working. When the sonde was taken outside and the filter removed, an increase in signal was measured, so we conclude that the filter was working correctly and that laboratory air was essentially ozone-free.

- correction to pump flow rate measurement for humidification of air. For a laboratory at $20^{\circ} \mathrm{C}$ and $50 \% \mathrm{RH}$ this correction reduces $F$ in Eq. (4) by around $1.5 \%$ (Smit et al., 2013), increasing ozone by the same amount - in other words equation 4 underestimates ozone by $\sim 1.5 \%$.

The overall effect of departures from the GAW recommendations is therefore small - much smaller than the error due to the background current uncertainty for tropical tropospheric ozone concentrations.

\subsection{Contamination}

A complication encountered during this experiment was the sudden appearance of a contamination source inside the TSC01 which produced a large signal from the ozonesonde. This badly affected the first two sondes, rendering their data unusable. These sondes were extensively exposed to air drawn through the TSC01 during their second preparation (the first having been completed normally before the contamination appeared). Contamination also rendered the calibration cell on the TSC01 unusable. Sondes 3 and 4 were again clean on first preparation but were briefly exposed to the TSC01 on second preparation, after an initial measurement of the background current. The remaining sondes were not exposed to the TSC01 at all during the second preparation - the sonde's response to ozone was assumed to be normal and the background current was measured by draw- ing air through an external charcoal filter. Sondes 5-14 were briefly exposed to the TSC01 on first preparation and were subsequently found to have elevated background currents. Sondes 15 onwards were not exposed at all to the TSC01 and the background currents from these sondes were around $50 \mathrm{nA}$ before launch.

Figure 2 shows how the background currents measured for each sonde varied during the campaign, compared to the minimum current measured by the cell in the TTL (taken from the Väisälä raw data telemetry). During the latter part of the campaign the background current was around half the minimum measured in the TTL, but during the early part the minimum current was close to or even lower than the background - implying an impossible negative ozone. Clearly the contamination did not remain constant during a flight.

On return from Manus a series of laboratory experiments were conducted to ascertain the properties of the contamination. These are summarised in the Appendix, but the salient result is that for lightly contaminated sondes (such as 3-15) the effects of the contamination tended to disappear over a similar timescale $-\sim 1 \mathrm{~h}-$ to that taken by a sonde to reach the TTL. Based on this, and the evidence in Fig. 2 that the minimum ozonesonde current in the TTL was remarkably stable over the campaign, we assume that in-flight the contamination disappeared and the background current returned to a value of $50 \mathrm{nA}$, consistent with the uncontaminated sondes. A hybrid background current correction was thus devised:

$I_{\mathrm{bg}}=50 \mathrm{nA}+\left(I_{\mathrm{bg}}^{\mathrm{meas}}-50 \mathrm{nA}\right) \frac{p}{p_{0}}$,

where $I_{\mathrm{bg}}^{\text {meas }}$ was the measured background current before launch, $p$ the pressure and $p_{0}$ the surface pressure.

The spread in measured background current for the uncontaminated sondes was around $10 \mathrm{nA}(0.01 \mu \mathrm{A}$, Fig. 2 , sondes 15 onwards), with a similar difference between the values measured at the beginning and the end of the preparation, so it is reasonable to estimate an uncertainty in $I_{\text {bg }}$ measured before flight of $\pm 10 \mathrm{nA}$. If $I_{\mathrm{bg}}$ were constant during flight this would correspond to an uncertainty of $\pm 3.4 \mathrm{ppbv}$ in the TTL. According to Thornton and Niazy (1983), $I_{\mathrm{bg}}$ should remain constant up to $100 \mathrm{mb}$, then decline logarithmically with pressure. Our laboratory investigations on an uncontaminated sonde (Fig. A3) suggest a small decrease of around $5 \mathrm{nA}$ in going from lab pressure to $100 \mathrm{mb}$, consistent with Thornton and Niazy's result within error limits. Taking this as an uncertainty (rather than a bias) in the variation of $I_{\text {bg }}$ we estimate the uncertainty in TTL ozone below $100 \mathrm{mb}$ to be \pm 5 ppbv. The cold-point tropopause during the campaign at Manus was always between 90 and $110 \mathrm{mb}$, with the ozone concentration increasing rapidly in this range: the minimum concentration was always found below $110 \mathrm{mb}$. Above $100 \mathrm{mb}$ the use of a constant $I_{\text {bg }}$ will tend to lead to an underestimate of ozone, but as ozone was generally $>50 \mathrm{ppbv}$ 


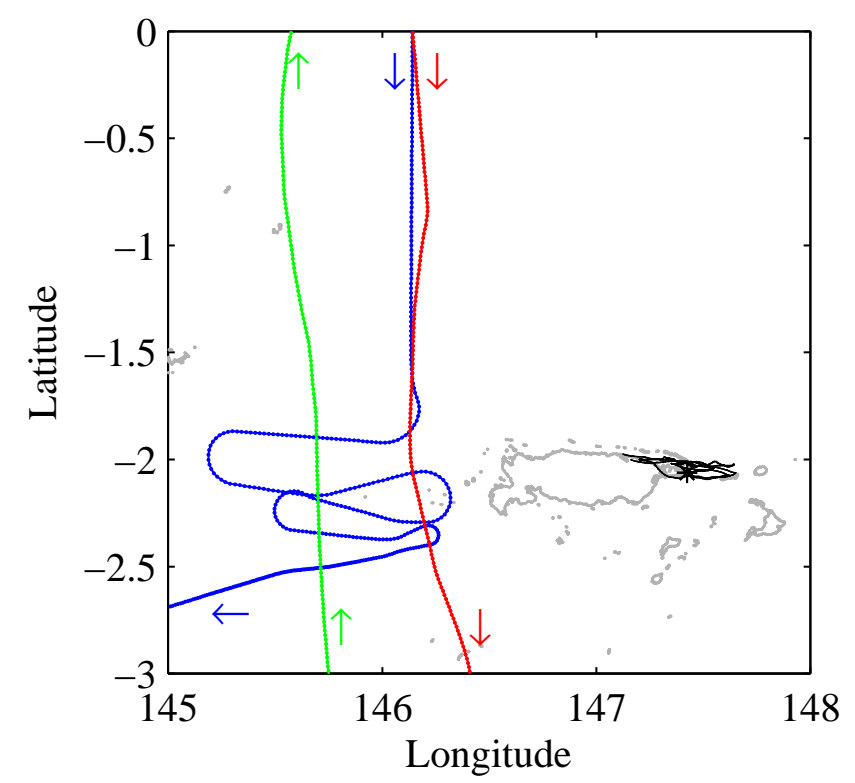

Figure 3. Map of the co-located measurements of Gulfstream V flights RF09 and RF14, and CAST ozonesondes 6, 34 and 35. The blue flight path is RF09, the red is the outbound leg of RF14 and green is the return leg of RF14. The black lines are the flight paths of ozonesondes 6, 34 and 35, which all remained in the east of Manus Island at all times. The arrows show the direction of travel of the Gulfstream V.

above $100 \mathrm{mb}$, and increasing rapidly with height, this effect is only manifested in the stratosphere.

The error in TTL ozone for the contaminated sondes cannot be assessed quantitatively but will certainly be greater than that for the uncontaminated sondes. We can only get an estimate of this error from a comparison with another technique, so we now turn to a comparison of ozonesonde profiles with aircraft measurements.

\section{Validation}

One of the aims of the CAST and CONTRAST campaigns was to investigate the accuracy of ozonesonde measurements in the TTL by comparing them with near-coincident aircraft measurements from the NCAR Gulfstream V. Ozone measurements on the Gulfstream V were made using the NCAR chemiluminescence instrument. The technique is based on the chemiluminescent reaction of $\mathrm{NO}$ and $\mathrm{O}_{3}$ to produce excited $\mathrm{NO}_{2}$, a fraction of which decays by emitting a photon (Ridley et al., 1992). A small flow of pure NO is added to a flow of ambient air and the resulting photons are counted using a dry-ice cooled photomultiplier tube. The instrument is periodically calibrated against a Thermo Scientific 49i-PS primary ozone standard on non-flight days. The overall uncertainty is $5 \%$, or $1 \mathrm{ppbv}$ at $20 \mathrm{ppbv}$. The precision of the measurements at $20 \mathrm{ppbv}$ is $0.1 \mathrm{ppbv}(0.5 \%)$, or better, for the $10 \mathrm{~s}$ averages used here.

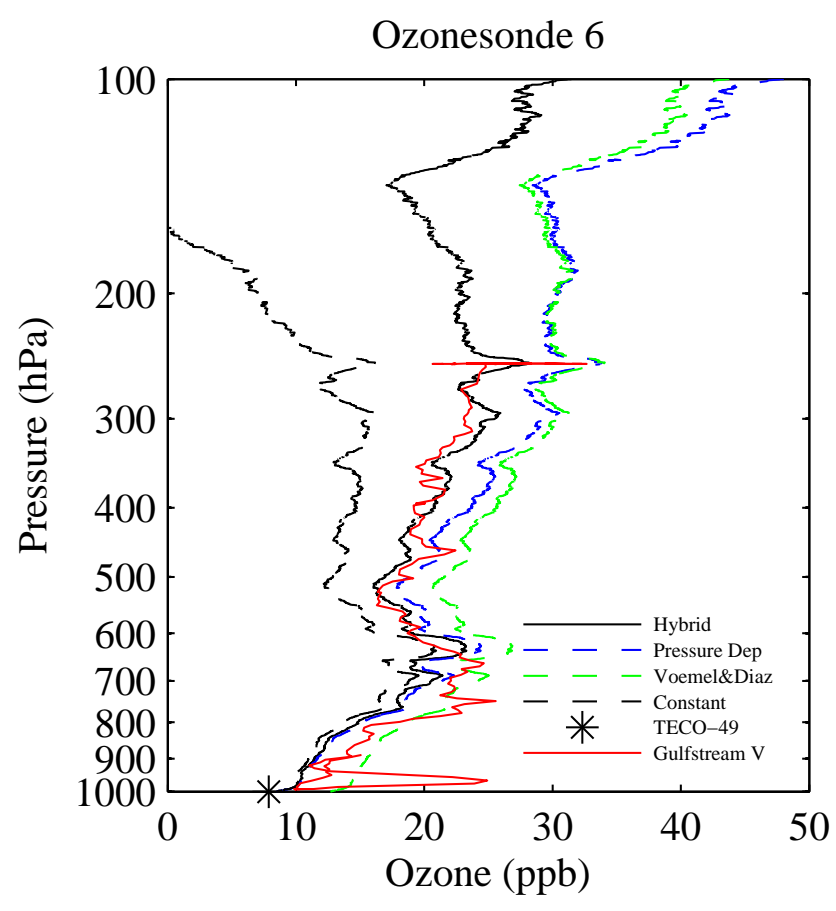

Figure 4. Ozone concentrations from CAST ozonesonde 6 on 5 February (black), and the segment of Gulfstream V flight RF09 that was close to Manus Island (red). The aircraft measurements most closely resemble the ozonesonde when the hybrid background correction is used (solid line), compared to the constant (black dotted line), pressure-dependent (red dotted line) and Vömel and Diaz (green dotted line) corrections. The asterisk is the ozone concentration measured by the TECO-49 on the ground on Manus Island. The peak in the aircraft data near the surface is caused by biomass burning.

On 5 February Gulfstream V flight RF09 flew to the west of Manus Island and profiled from the surface to $\sim 11 \mathrm{~km}$. Figure 3 shows the path of ozonesonde 6 and the Gulfstream V flight segment near Manus, and Fig. 4 compares their ozone profiles. Ozonesonde 6 was affected by contamination with a high background current (143 nA). In Fig. 4, four ozonesonde profiles are shown - one using a constant background current correction (black dashed line), one using a pressure-dependent correction (blue dashed line), one using the recommendation of Vömel and Diaz (2010) (green dashed line) and the fourth using the hybrid correction (solid black line). It is clear that the hybrid correction fits the Gulfstream $\mathrm{V}$ measurements (red solid line) very well, while the constant correction gives artificially low (and in this case negative) ozone in the TTL similar to the profiles reported by Kley et al. (1996) and Rex et al. (2014). We conclude that the hybrid correction provides a satisfactory estimate of $I_{\text {bg }}$ but reiterate the point made in the previous section that a quantitative error estimate in TTL ozone for the contaminated sondes is not possible. 


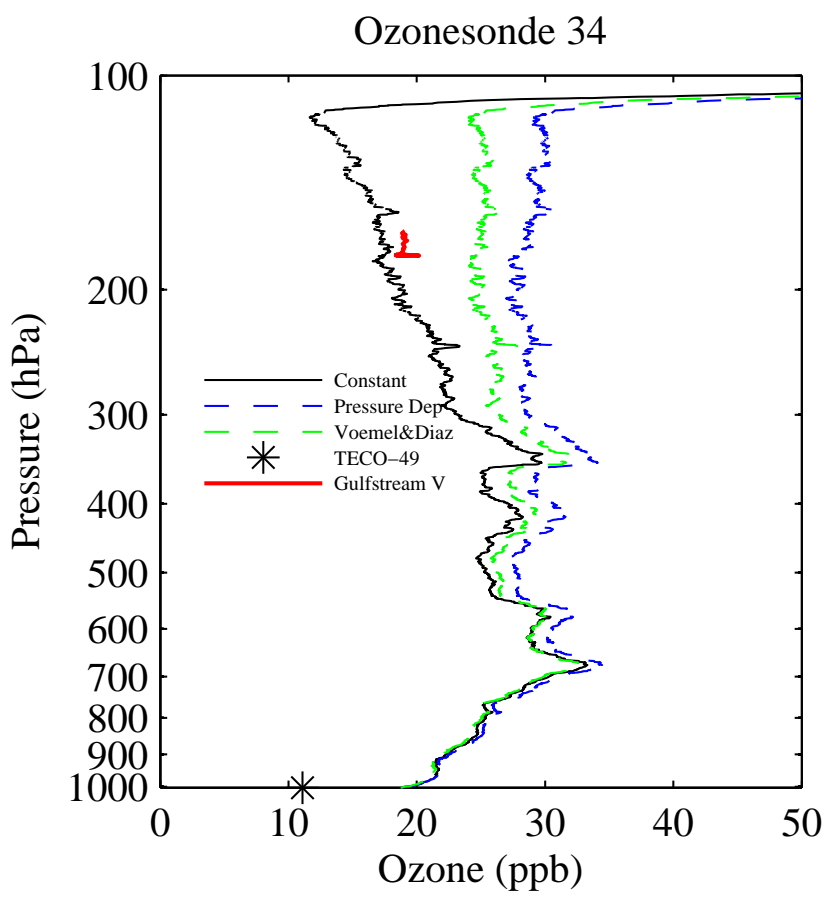

Figure 5. As Fig. 4 for CAST ozonesonde 34 and outbound leg of Gulfstream V flight RF14 on 22 February.

Gulfstream V flight RF14, on 22 February, passed just to the west of Manus on two occasions - on an outbound journey towards Australia and then on the return journey back to Guam. On both occasions, an ozonesonde was launched so as to reach aircraft altitude as the aircraft made closest approach to Manus. Ozonesonde 34, coincident with the outbound leg, was launched at 01:31 UTC (11:31 LT) and reached the Gulfstream $\mathrm{V}$ cruising altitude of $13.5 \mathrm{~km}$ at 02:11 UTC. In the flight-path map in Fig. 3, the red line is the outbound leg of RF14. Figure 5 shows the ozone profiles from ozonesonde 34 and the co-located measurements of RF14. Likewise ozonesonde 35, launched at 04:49 UTC (14:49 LT) coincided with the return leg of RF14, reaching the Gulfstream V cruising altitude of $180 \mathrm{hPa}(13.5 \mathrm{~km})$ at 05:29 UTC. On this leg the aircraft executed a profile between 13.1 and $14.7 \mathrm{~km}$ as it passed by Manus. Figure 3 shows the flight-path of the return leg in green. Figure 6 shows the profiles from ozonesonde 35 and the co-located measurements from RF14.

Ozonesondes 34 and 35 were uncontaminated, so constant background currents of 61 and $54 \mathrm{nA}$ respectively were used in the data analysis. In both cases, the agreement between the ozonesonde and the aircraft data is within 3 ppbv - consistent with the uncertainty in the background currents. By contrast, the pressure-dependent correction and that recommended by Vömel and Diaz (2010) clearly overestimate the ozone concentration. We therefore conclude that for a wellconditioned ozonesonde not exposed to ozone at all in the pre-flight preparation, where the background current at the

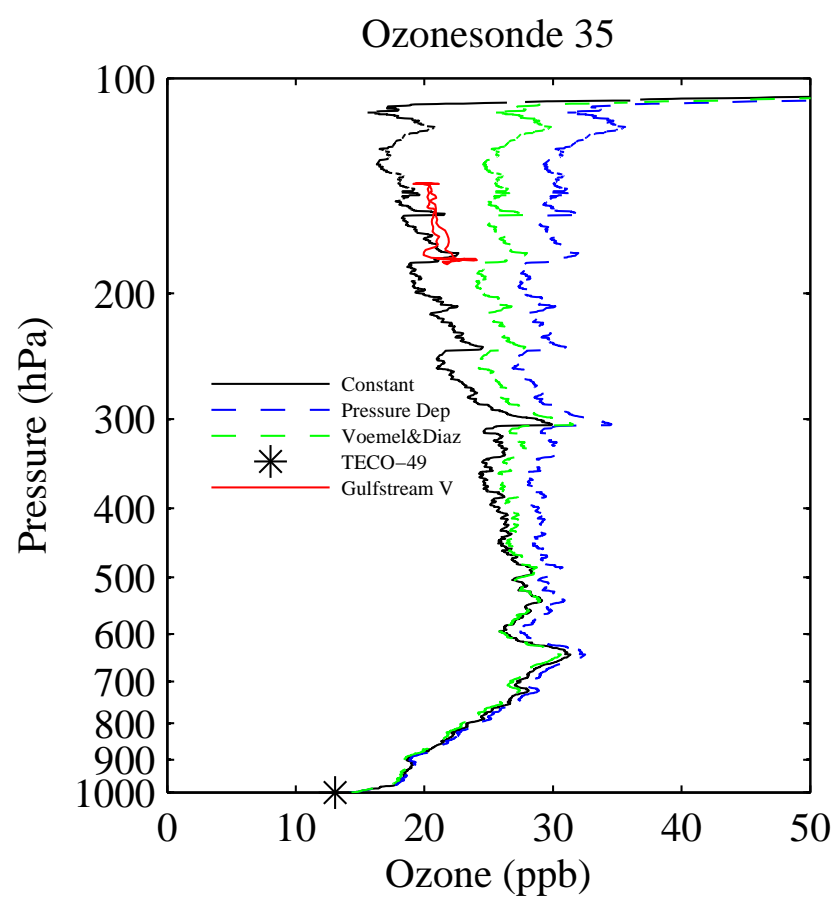

Figure 6. As Fig. 4 for CAST ozonesonde 35 and inbound leg of Gulfstream V flight RF14 on 22 February.

end of the preparation is around $50 \mathrm{nA}$ or less, subtraction of this constant background produces an ozone measurement in the TTL within a few ppbv of the correct value. We also conclude that our method of applying a hybrid correction produces sensible results for the contaminated sondes.

What we cannot be sure of is whether the hybrid method applies only to this particular batch of sondes, or whether it can be applied more generally to sondes where the background current in the preparation is substantially larger than $50 \mathrm{nA}$. To check this, we reanalysed an ozonesonde profile from the ACTIVE campaign in Darwin, launched on 22 January 2006. This had a background current of $85 \mathrm{nA}$ which, when subtracted from the measured currents, resulted in an ozone concentration minimum of $4 \mathrm{ppbv}$ in the TTL. A sonde the following day with a very similar ozone profile but a background current of $55 \mathrm{nA}$ measured a minimum ozone mixing ratio of $12 \mathrm{ppbv}$. Applying the hybrid correction to the sonde on 22 January increased the minimum value in the TTL to $12 \mathrm{ppbv}$, in line with the other sonde. This suggests that the hybrid method may have wider validity than the Manus data set and may be worth investigating further. (We should emphasise that not all ozonesonde measurements $<10 \mathrm{ppbv}$ in the TTL are artifacts of elevated background currents: the lowest measured in Darwin was $8 \mathrm{ppbv}$ on 15 February 2006 with a background current of $37 \mathrm{nA}$.)

We have therefore applied the following background current correction to the Manus data set, after discarding the first two profiles: 


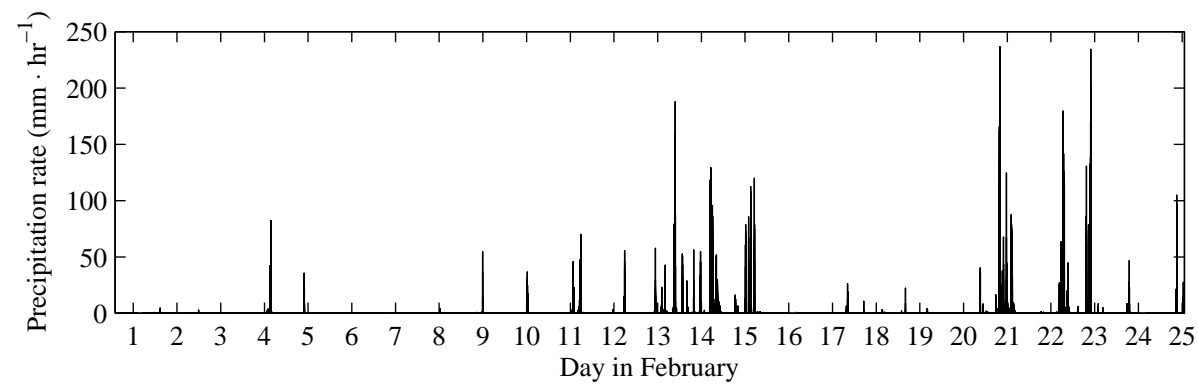

Figure 7. Time series of precipitation rate (in $\mathrm{mm} \mathrm{hr}^{-1}$ ) measured by an optical rain gauge at the Manus Island ARM site. Data courtesy of ARM archive.

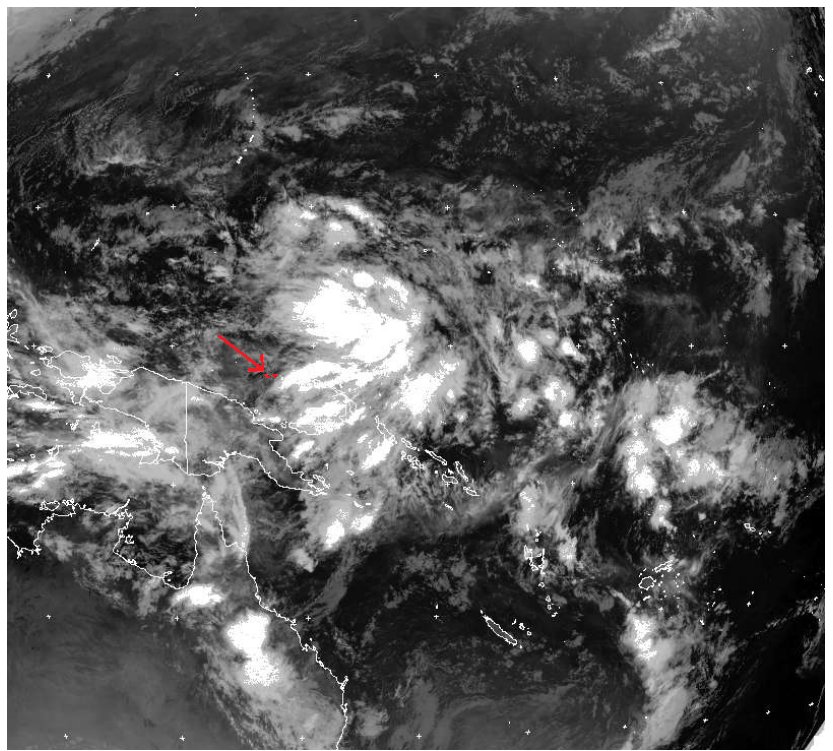

Figure 8. MTSAT channel 2 (near-infrared) image from 19 February 2014, 18:00 UTC. The convection to the east of Manus Island (red arrow) is visible as the brightest clouds in the image.

- For sondes 3 and 4, a hybrid correction was applied using $I_{\mathrm{bg}}$ measured at the beginning of the second preparation, before exposure to the TSC01 ozoniser. This value was considerably smaller that measured after exposure to the ozoniser, but higher than the $\sim 50 \mathrm{nA}$ typical of the uncontaminated sondes.

- For sondes 5 to 14 , a hybrid correction was applied using $I_{\text {bg }}$ measured just before launch.

- For sondes 15 on, a constant value of $I_{\mathrm{bg}}$ was applied equal to that measured just before launch.

Note that for sondes 15 onwards $I_{\mathrm{bg}}$ measured at the beginning and end of the second preparation were very similar (Fig. 2).

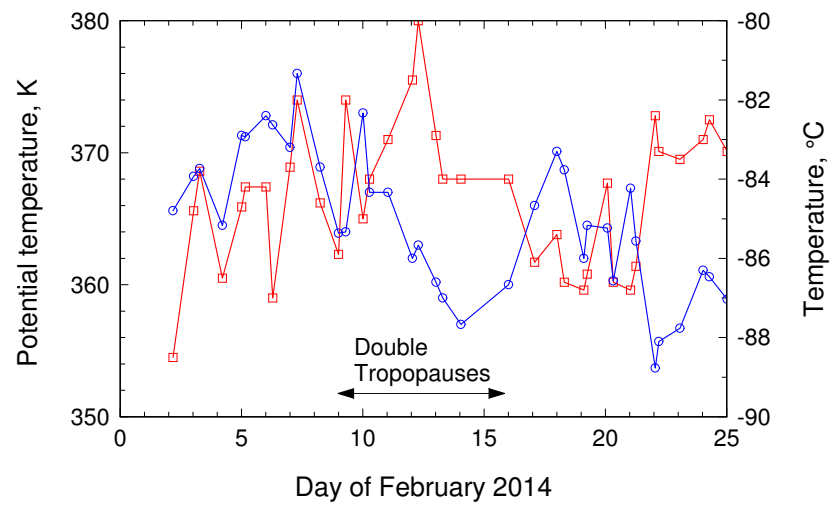

Figure 9. Variation of cold point tropopause temperature (red curve, right axis) and cold point potential temperature (blue curve, left axis) measured by the CAST sondes. Where double tropopauses were observed (between 9 and $16 \mathrm{Feb}$ ), the local temperature minimum corresponding to a steep increase in ozone concentration was taken as the tropopause. In these cases the coldest point lay around 1-2 km higher.

\section{Results}

We present here an overview of the measurements made at Manus during CAST. The campaign experienced two distinct weather regimes - a dry period from around 1-10 February with little precipitation (Fig. 7) when deep convection was well to the south of Manus, and a wetter period from 11 February on, with two particularly wet periods around 1315 February and 20-23 February. During the latter period in particular, widespread deep convection occurred around and to the east of Manus (Fig. 8), providing the conditions needed to examine the ozone concentration in fresh convective outflow.

The two meteorological regimes are reflected in the time series of tropopause (cold point) temperature and potential temperature from the ozonesondes (Fig. 9), with $\theta$ generally around $370 \mathrm{~K}$ from 1-12 February and rather lower, around $364 \mathrm{~K}$, from 13 February onwards. Tropopause heights and pressures for the whole campaign (not shown) ranged from 15.7 to $17.2 \mathrm{~km}$, and 89 to $115 \mathrm{hPa}$ respectively. Dou- 

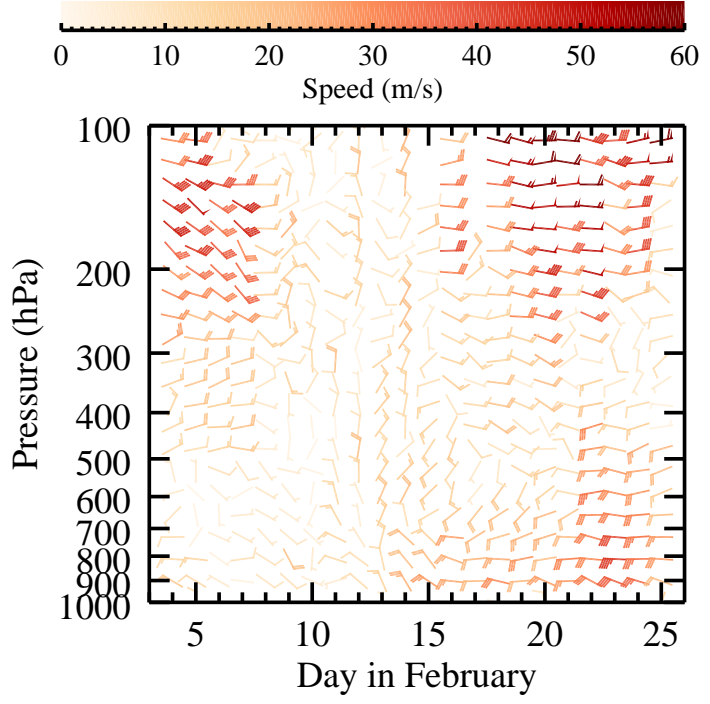

Figure 10. Wind speed (in $\mathrm{m} \mathrm{s}^{-1}$ ) and wind barbs (in knots), measured by the CAST sondes between 0 and $18 \mathrm{~km}$. Note the easterly jet in the TTL between 19 and 21 February, coincident with the low ozone found in Fig. 11.

ble tropopauses were found from 9 to 16 February; the tropopause shown in Fig. 9 corresponds to the first steep increase in ozone concentration as the balloon ascended. (The cold point during this period was around $-86^{\circ} \mathrm{C}$.) Following the period of double tropopauses, on 18 February, the tropopause was at $370 \mathrm{~K}(17 \mathrm{~km})$, but as the very wet conditions became more established it descended to reach $354 \mathrm{~K}$ $(15.7 \mathrm{~km})$ on 22 February. At the same time a distinctive feature became established in the wind field (Fig. 10): from 16 February onwards, and especially from 20-23 February, an easterly jet with wind speed up to $40 \mathrm{~m} \mathrm{~s}^{-1}$ was found in the TTL, just below the tropopause. This jet was confined to the troposphere - by $1.5 \mathrm{~km}$ above the tropopause the wind had backed round to westerly, and remained westerly between 18 and $26 \mathrm{~km}$. A corresponding minimum in wind speed (of $\leq 2 \mathrm{~m} \mathrm{~s}^{-1}$ in most cases) was measured 700$1200 \mathrm{~m}$ above the tropopause from 16 February onwards. This easterly jet is consistent with convective outflow from the large convective complexes to the east of Manus (Fig. 8) reaching up to the tropopause during this period but not extending into the stratosphere.

The corresponding contour plot of ozone concentration is shown in Fig. 11. This clearly shows the "S" shape expected of tropical ozone soundings, with low values near the surface and in the TTL, and a maximum in the mid-troposphere. Minimum values of $<20 \mathrm{ppbv}$ are frequently shown in the TTL, around $14 \mathrm{~km}$ during the first meteorological period and then up to $16.5 \mathrm{~km}$ during the second period. The periods of precipitation in Manus (Fig. 7) both correspond to ozone concentrations $<20 \mathrm{ppbv}$ reaching the tropopause, and indeed in the very wet period between 20 and 22 February,

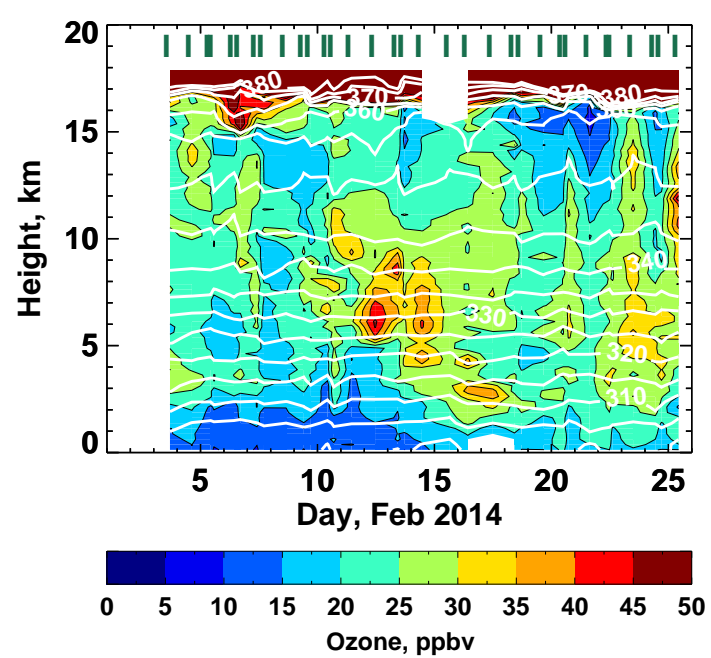

Figure 11. Ozone concentration (ppbv) measured by the CAST ozonesondes between 0 and $18 \mathrm{~km}$ during February 2014, overlaid with potential temperature ( $\mathrm{K}$, white contours). Green bars at the top denote the launch times of individual ozonesondes.

when the TTL easterly jet was at its most intense, ozone minimum concentrations fell to $<15$ ppbv. The lowest measured value was $8.2 \mathrm{ppbv}$ on 21 February - a similar minimum to that measured in Darwin during ACTIVE. This may have been an outlier (its background current was $60 \mathrm{nA}$ ), but five sondes reached between 12 and 13 ppbv (e.g. sonde 34 on 22 February, Fig. 5) and a further four between 13 and $15 \mathrm{ppbv}$. These values are entirely consistent with the minimum ozone concentration of 13 ppbv measured by the Gulfstream V during CONTRAST (Pan et al., 2015).

To confirm that the very low ozone measured in the TTL is consistent with uplift from the deep convection to the east of Manus, back-trajectory calculations were performed using the HYSPLIT on-line model. As an example, Figs. 12 and 13 show 4-day HYSPLIT back-trajectories initiated over Manus at 02:00 UTC on 22 February (corresponding to sonde 34), between $13 \mathrm{~km}(180 \mathrm{hPa})$ and $15 \mathrm{~km}(130 \mathrm{hPa})$. The trajectories clearly indicate extensive uplift from the lower troposphere in the $48 \mathrm{~h}$ before the measurement, indicating that the source of the low ozone in the TTL is indeed the lower troposphere north of the Solomon Islands. Of course, the HYSPLIT trajectories cannot represent ascent in individual cloud systems, and so cannot determine whether the air is really of boundary-layer origin, but they do confirm that the meteorological conditions at this time were consistent with widespread deep uplifting of air.

Figure 11 shows that the low-level ozone over Manus also showed two distinct periods, consistent with the meteorology. Ozone concentrations $<15 \mathrm{ppbv}$ extended up to $2 \mathrm{~km}$ in the dry period and persisted below $1 \mathrm{~km}$ up to 14 February, but in the very wet period the lowest values were in the range 15-20 ppbv, more than the minima measured in the TTL. 


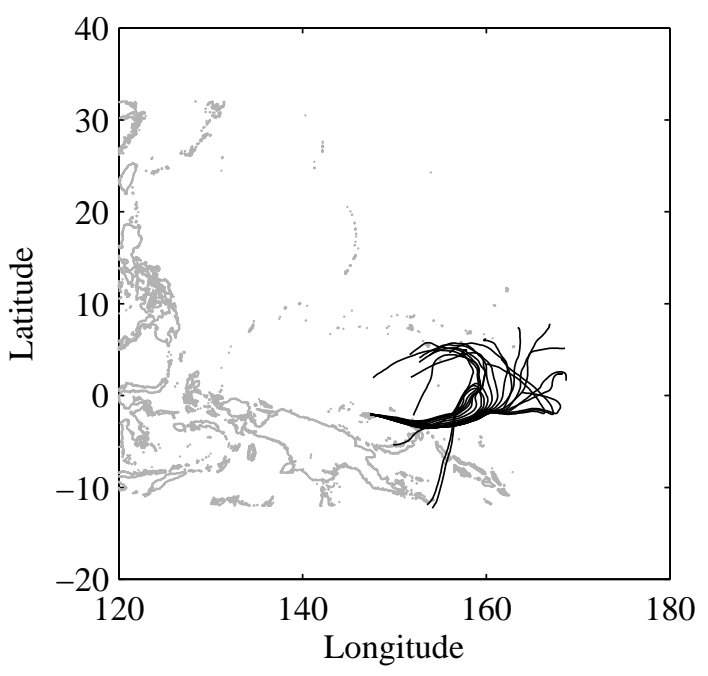

Figure 12. Map of the 21 HYSPLIT back-trajectories initiated from Manus Island at $100 \mathrm{~m}$ intervals from 13 to $15 \mathrm{~km}$. The trajectories mostly come from the north-east of Manus Island, in the same location as the area of deep convection seen in Fig. 8.

However, the ground-level measurements from the TECO-49 ozone monitor (Fig. 14) tell a rather different story. The dry early period of the CAST campaign, from 1 to 12 February, was characterized by a strong diurnal variation in ozone, with maxima of $\sim 8-10 \mathrm{ppbv}$ during the day and minima $\sim 2-$ $3 \mathrm{ppbv}$ at night. Winds were very light and variable, allowing the boundary layer to stabilise overnight, so we deduce that the night-time minima during this period were a local phenomenon. Wetter conditions set in by 13 February, with the diurnal ozone variation largely disappearing in the steady north-westerly breeze. Ozone concentrations in the range 913 ppbv predominated up to 19 February, with $12-14$ ppbv thereafter. These values are in fact consistent with the minimum values measured in the TTL (save for the very low value on 21 February) - and with the sondes, which generally measured a steep increase in ozone in the bottom $200 \mathrm{~m}$ of the profile (the altitude scale in Fig. 11 obscures this point). If the lower tropospheric ozone in the uplift region to the east of Manus was similar to that over the island, this would suggest that the air reaching the very top of the TTL in the wet period originated very near to the surface and was lifted to the tropopause without significant mixing with surrounding air, consistent with the suggestion of Kley et al. (1996).

\section{Conclusions}

One of the aims of this paper was to determine the best way to correct ozonesonde profiles from a tropical station for the effect of the background current. We were very fortunate that the Gulfstream V flight RF14 was able to fly by Manus during the period when very low ozone concentrations were observed in the TTL by the sondes. Ozonesondes 34 and 35

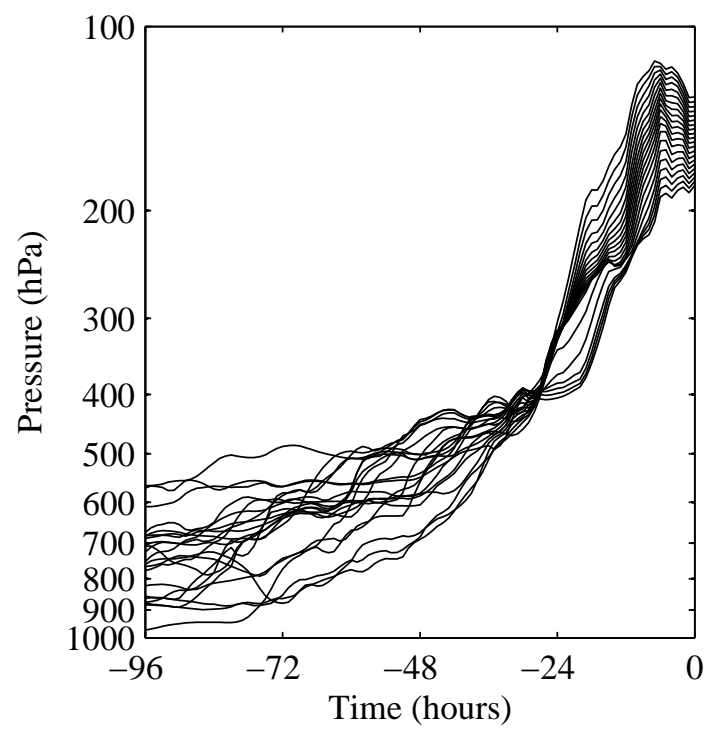

Figure 13. Pressure plot of the HYSPLIT back-trajectories. Zero time is defined as the initialization time of the back trajectories, at 02:00 UTC on 22 February 2014.

were free of contamination, and when using a constant background current measured just before launch their measurements agreed with the Gulfstream V to within 3 ppbv (the realistic limit on the accuracy of the ozonesonde at $100 \mathrm{mb}$ is \pm 5 ppbv due to background current uncertainty). We conclude that for a well-prepared sonde -i.e., (for the batch used here) one where $I_{\mathrm{bg}} \sim 50 \mathrm{nA}-\mathrm{a}$ constant background current correction is the best choice.

In preparing these sondes we found it necessary to change solutions in the cells up to three times during a day-of-flight preparation in order to ensure a sufficiently low background current. Other than for sondes 3 and 4, we also did not expose the sondes to ozone during the day-of-flight preparation, which removes the problem of the slow decay in $I_{\mathrm{bg}}$ after such exposure (Vömel and Diaz, 2010). Both these changes in standard procedures are recommendations from this work. For the sondes exposed to contamination during first preparation a hybrid background current correction was adopted after the laboratory investigation. Using this, the profile for sonde 6 was found to agree remarkably well with the aircraft profile from RF09 (Fig. 4), lending confidence to this somewhat arbitrary correction. Care must be taken not to generalise this result too far, but we can conclude (both from the CAST sondes from Manus and the ACTIVE sondes from Darwin) that a background current in excess of $70 \mathrm{nA}$ is too high for a constant $I_{\text {bg }}$ correction - as shown by Vömel and Diaz (2010) this leads to a substantial underestimate of the TTL ozone and even to negative ozone in some cases (e.g. Rex et al., 2014).

The minimum reproducible ozone concentration measured in the TTL during CAST was $12 \mathrm{ppbv}$, consistent with the minimum of $13 \mathrm{ppbv}$ measured between 12 and $15 \mathrm{~km}$ by the 


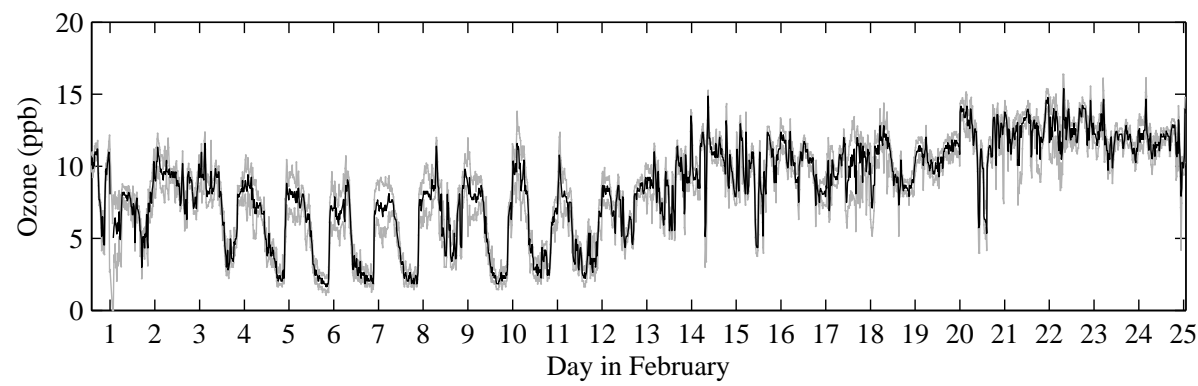

Figure 14. Time series plot of ozone concentration (in ppbv) measured on the ground by the TECO-49 ozone monitor. The black line is the 15 min median ozone concentration, and the grey lines are the 10th and 90th percentiles. A strong diurnal cycle is established between 3 and 12 February, which disappears on 13 February, replaced by a higher, more constant ozone concentration of $\sim 12$ ppbv.

Gulfstream V during CONTRAST (Pan et al., 2015). This is also consistent with the minimum measured in Darwin with well-prepared sondes (12 and $11 \mathrm{ppbv}$ on 23 January and 14 February 2006, respectively) in air whose origin, according to back-trajectory calculations, lay in deep convective uplift east and north-east of New Guinea. In both campaigns an isolated example of a lower concentration, around 8-9 ppbv, was also measured. The CAST measurements confirm Vömel and Diaz (2010)'s conclusions that ozonesonde measurements $<5 \mathrm{ppbv}$ in the TTL are artifacts of the background current correction.
The lowest ozone concentrations measured in the TTL above Manus occurred around $16 \mathrm{~km}$ during a period when widespread deep convection was occurring near and to the east of the island. This is consistent with the 'hot spot' idea proposed by Heyes et al. (2009) for uplift of air to the upper TTL. The lowest ozone concentrations coincided with an easterly jet, consistent with outflow from the deep convective complexes. At this time, the ozone concentration in the lowest $2 \mathrm{~km}$ over Manus exceeded $15 \mathrm{ppbv}$ - only at the ground and in the bottom $200 \mathrm{~m}$ of the profile could values as low as $12 \mathrm{ppbv}$ be found. This suggests that the widespread deep convection was able to lift air from the lower boundary layer into the upper TTL without significant mixing - a hypothesis we cannot pursue further here but which will be the subject of future investigations. 


\section{Appendix A: Laboratory experiments}

When the pattern found in Fig. 2 was discovered, the records of the CAST field campaign were examined (Sect. A1) and a series of laboratory experiments devised to ascertain the reasons why the background current generally decreased between sondes 5 and 14 yet the minimum measured current in the TTL remained reasonably constant. It was observed that when an ozonesonde drew air from the TSC01 ozoniser unit, a high current was registered. This was identified in the laboratory experiments as being contamination, rather than high concentrations of ozone, as explained in Sect. A2.

Neither the source nor the identity of the contamination was known, and so an experiment was devised to determine the response of an ozonesonde to pressure with various degrees of contamination, by placing it into a bell jar and varying the pressure. The results of this experiment are described in Sect. A3. The contamination gradually disappeared over time, so the bell jar experiments were neither reproducible nor did they replicate exactly the conditions that were experienced on Manus, but they serve as a check on the validity of the hybrid background current correction.

\section{A1 Examination of records}

The first five ozonesondes were normal on first preparation. Between the fifth ozonesonde being prepared for the first time and the following day when the first ozonesonde was being prepared for flight, the ozoniser was found to be causing the cell current to increase dramatically even when it was supplying "no-ozone" air. This affected the first two ozonesondes' day-of-flight preparations, and their background current remained well above that of a normal working ozonesonde. Thenceforth, an external ozone destruction filter was used instead of the ozoniser to produce no-ozone air and the sonde was not exposed to the ozoniser during the day-of-flight preparation. However, ozonesondes 6 to 14 were briefly exposed to the ozoniser during their first preparation to check the response of the sonde to ozone. Since exposure to the ozoniser was resulting in elevated background currents, the ozonesonde sample tube was only connected to it for a few seconds before being removed. However, this turned out to be long enough to allow the contaminant to get into the ozonesonde where it remained throughout the preparations.

Ozonesondes 15 onwards were not exposed to the ozoniser at all, and were therefore the most reliable ozonesondes launched during CAST.

\section{A2 Source of contamination}

In order to investigate the cause of the high background currents in the first 14 ozonesondes, laboratory investigations were conducted after the equipment was returned from
Manus to Manchester, some 2 months after the campaign ended.

First, the response of an ozonesonde was compared with that of the TECO-49 ultraviolet photometric ozone monitor. When sampling laboratory air, both TECO-49 and the ozonesonde measured comparable concentrations $(\sim 22 \mathrm{ppbv})$, and when drawing air through the external charcoal filter the sonde measured 2 ppbv while the TECO49 measured 12 ppbv. However, when sampling supposedly ozone-free air from the ozoniser (air drawn through an internal charcoal filter) the sonde measured $189 \mathrm{ppbv}$ while the TECO-49 again measured 12 ppbv. Clearly, therefore, the ozoniser was acting as a source of some contaminant which produced a positive signal in the ozonesonde but not in the photometric ozone monitor - i.e., this substance was not ozone. (The 12 ppbv signal measured by the TECO through the filters is understandable as the flow rate of the TECO-49 is much higher than the ozonesonde and exceeds the capacity of the filters). Further investigation, dismantling the ozoniser and examining different parts, identified the source of the contamination as the tube which is illuminated by a mercury lamp to generate ozone. However, contamination was found even on the PTFE manifold at the outlet of the ozoniser.

A plausible explanation for the contamination, pointed out by one of the reviewers, is that condensation of water occurred inside the tube at some point, which, when irradiated by ultraviolet light, led to the production of hydrogen peroxide. $\mathrm{H}_{2} \mathrm{O}_{2}$ is known to react with $\mathrm{KI}$ in the cathode cell with a very slow response time (Cohen et al., 1967), consistent with the behaviour of the contaminant, and to stick to surfaces for a long time. The contaminant appeared first thing in the morning when the equipment had been enclosed in the air-conditioned laboratory overnight.

\section{A3 Ozonesonde behaviour at different pressures}

The effect of lowering the ambient pressure on the contamination was then investigated by placing the ozonesonde in a bell jar and lowering the pressure as the sonde continually sampled the air inside the bell jar. The bell jar was too small to admit the ozone destruction filter but ozone measurements inside the jar at ambient pressure were the same as in the laboratory with the filter attached; thus air in the bell jar was ozone-free. Three ozonesondes were exposed to different amounts of contaminant by drawing air through the TSC01 unit for different times: the first was heavily contaminated, the second slightly contaminated, and the third not contaminated at all. The ozonesonde was placed in the bell jar and left to settle to a constant background current for about $5 \mathrm{~min}$. The bell jar was then pumped down to a target pressure using a rotary pump, and then the rotary pump was switched off. The ozonesonde was left for $5 \mathrm{~min}$ to settle and reach a constant background current, and then a new target pressure was chosen. 


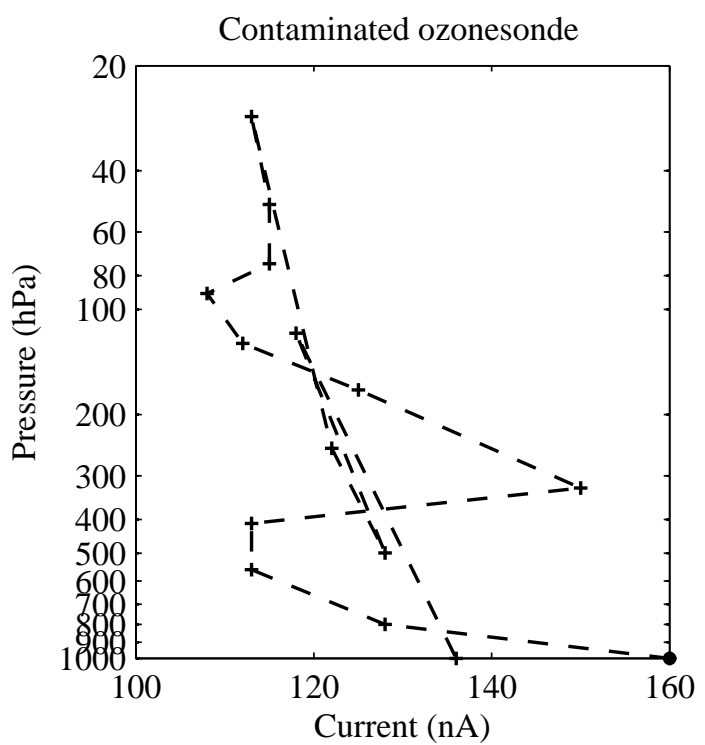

Figure A1. Current measured at each pressure for the contaminated ozonesonde. The dashed line shows the order in which the measurements were taken, starting from $(1000 \mathrm{hPa}, 160 \mathrm{nA})($ the $\bullet$ data point).

The first, heavily contaminated ozonesonde emulated the first two ozonesondes launched in CAST, which were prepared just after the contamination episode, but before the contamination was recognised. The slightly contaminated ozonesonde emulated ozonesondes 3 to 14 , which were only contaminated on first preparation. Ozonesondes 15 onwards were not contaminated, like the third test ozonesonde in this experiment.

The heavily contaminated ozonesonde was contaminated on both first preparation and the day-of-flight preparation and had a background current of $132 \mathrm{nA}$, which is comparable to the early ozonesondes in CAST. Figure A1 shows the result of the bell jar experiment. The current was erratic, which was observed with the contaminated ozonesondes during CAST: the current occasionally spiked by $\sim 20 \mathrm{nA}$, possibly due to the cell picking up more contamination. The most likely behaviour of the ozonesonde was a decay of the background current from $135 \mathrm{nA}$ at surface pressure to $115 \mathrm{nA}$ at $20 \mathrm{hPa}$, still well above the expected value for a well-functioning sonde. This confirms that a reliable background current estimate could not be made for the first two CAST sondes. The ozonesonde used in this experiment was subjected to a further preparation cycle (without exposure to contaminant) to investigate whether it could be cleaned. Its background current reached $40 \mathrm{nA}$ after $15 \mathrm{~min}$ of no-ozone-air treatment, indicating that the contamination was changing its character over time: changing solutions in the Manus sondes did not remove the contamination.

The second ozonesonde was initially contaminated in first preparation, and then prepared cleanly in the day-of-flight

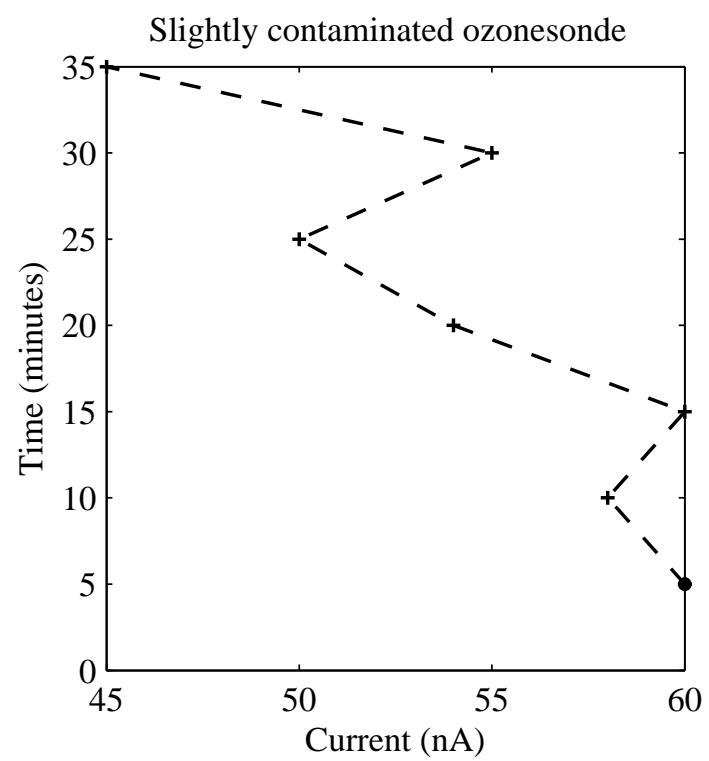

Figure A2. Current measured from the slightly contaminated ozonesonde as a function of time.

preparation, similar to ozonesondes 3-14 in Manus. However, as with the first test sonde, the contamination was found to disappear so that the "day-of-flight" background current was $55 \mathrm{nA}$ - consistent with a clean ozonesonde. It appears than that the contaminant changed its nature and became less adhesive over the 3-month period since the contamination event. More contaminant was therefore added at the end of the second preparation, bringing the background current to $80 \mathrm{nA}$. The bell jar experiment showed little consistency in the background current as a function of pressure, but a clear decay over time (Fig. A2). Since in a normal ozonesonde launch pressure decreases as a function of time, this gives weight to the idea that a decaying background current correction with pressure is appropriate for the slightly contaminated ozonesondes.

The uncontaminated ozonesonde was prepared cleanly both times, and had a background current of $45 \mathrm{nA}$. Figure A3 shows the result of the bell jar experiment. The experiment was split into two sections, one in which the ozonesonde remained above $200 \mathrm{hPa}$ at all times, followed by another in which the pressure was pumped down to $70 \mathrm{hPa}$. The current decreased slightly between 1000 and $100 \mathrm{hPa}$ (45-40 nA), before decreasing to $27 \mathrm{nA}$ at $70 \mathrm{hPa}$. This is similar to the result found by Thornton and Niazy (1983), which was attributed to a change in the mass transfer inside the ozonesonde. Within experimental accuracy of $\pm 10 \mathrm{nA}$, therefore, a constant background current is appropriate to the uncontaminated ozonesondes up to $100 \mathrm{hPa}$, with a possible decrease above this level. As the tropopause pressure encountered in Manus was $>90 \mathrm{hPa}$, with the ozone concentration increasing rapidly into the stratosphere, we have used a constant background current throughout the profile for un- 


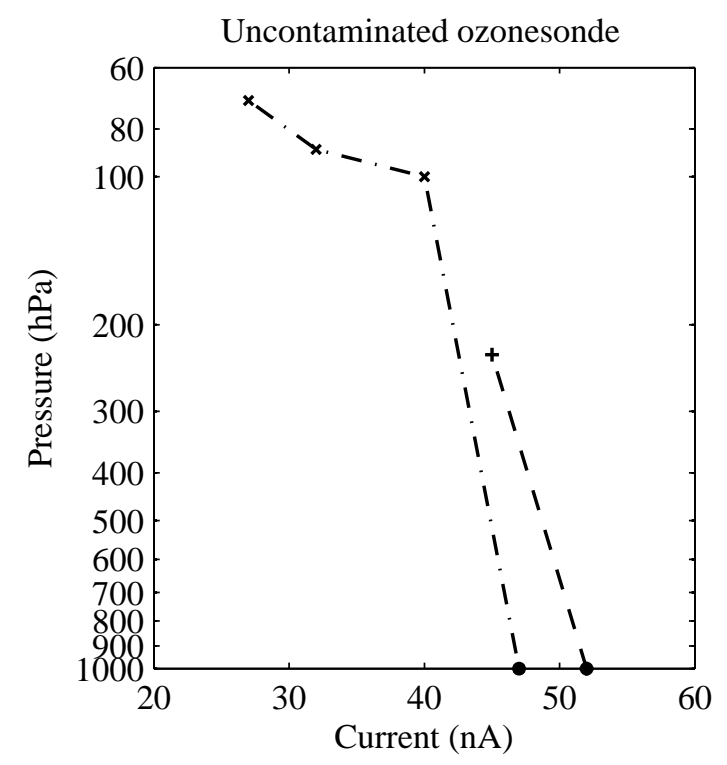

Figure A3. Figure showing the current measured at each pressure for the uncontaminated ozonesonde. The sonde was tested up to $250 \mathrm{hPa}$ in the first experiment (dashed line), before being brought back to surface pressure and then tested up to $70 \mathrm{hPa}$ (dash-dot line). Only the data points that simulate ascent are shown.

contaminated sondes. (Note that the ozonesonde in this test exhibited hysteresis when exposed to pressures lower than $100 \mathrm{hPa}$.)

\section{A4 Conclusions from laboratory experimentation}

The laboratory experiments could not reproduce the exact conditions experienced in Manus because the contamination was gradually disappearing and becoming less adhesive over time. This is consistent with the general decrease of background current between sondes 5 and 14 in Manus, despite their identical preparation procedure. Nevertheless, the behaviour is sufficiently similar to the CAST sondes as to provide support for the method used in Eq. (5) to calculate the background current.

The bell-jar experiments show that the background current in this batch of ozonesondes was largely constant in the absence of contamination, while that in a slightly contaminated ozonesonde reduced with time to a "clean" value over a period of $\sim 30 \mathrm{~min}$. This decay in $I_{\mathrm{bg}}$ is consistent with the slow timescale for the reaction of KI with peroxide identified by Cohen et al. (1967). The heavily contaminated ozonesonde did not reduce to an acceptable background current, confirming that data from the heavily contaminated ozonesondes launched in CAST should be discarded. 
Acknowledgements. We thank the Atmospheric Radiation Measuring Programme, in particular Paul Ortega, Kim Nitschke and Laurel Chapman, for extensive logistical support in enabling operations in Manus, and to Mae S. Chu for organising the shipping. Hymson Waffi and his staff, and the ARM technicians Mike Ryczek and Matt Gould, provided invaluable support on-site. We also thank Herman Smit, Neil Harris and Dale Hurst for valuable discussions, and an anonymous reviewer for pointing out that the contaminant could be $\mathrm{H}_{2} \mathrm{O}_{2}$. The project was supported by NERC grant NE/J006173/1, and the National Centre for Atmospheric Science Atmospheric Measurement Facility (AMF) provided the radiosonde and ground-level ozone equipment. Richard Newton is a NERC-supported research student.

Edited by: S. Brown

\section{References}

Cohen, I. R., Purcell, T. C., and Altshuller, A. P.: Analysis of the Oxidant in Photooxidation Reactions, Environ. Sci. Technol., 1, 712-715, 1967.

Folkins, I., Loewenstein, M., Podolske, J., Oltmans, S. J., and Proffitt, M.: A barrier to vertical mixing at $14 \mathrm{~km}$ in the tropics: Evidence from ozonesondes and aircraft measurements, J. Geophys. Res., 104, 22095, doi:10.1029/1999JD900404, 1999.

Folkins, I., Braun, C., Thompson, A. M., and Witte, J.: Tropical ozone as an indicator of deep convection, J. Geophys. Res., 107, 4184, doi:10.1029/2001JD001178, 2002.

Fueglistaler, S., Dessler, A. E., Dunkerton, T. J., Folkins, I., Fu, Q., and Mote, P. W.: Tropical tropopause layer, Rev. Geophys., 47, RG1004, doi:10.1029/2008RG000267, 2009.

Gettelman, A. and Forster, P. M.: A Climatology of the Tropical Tropopause Layer, J. Meteorol. Soc. Jpn., 80, 911-924, 2002.

Gostlow, B., Robinson, A. D., Harris, N. R. P., O’Brien, L., Oram, D. E., Mills, G. P., Newton, H. M., Yong, S., and Pyle, J. A.: $\mu$ Dirac: an autonomous instrument for halocarbon measurements, Atmos. Meas. Tech., 3, 507-521, doi:10.5194/amt-3-5072010, 2010.

Heyes, W. J., Vaughan, G., Allen, G., Volz-Thomas, A., Pätz, H.W., and Busen, R.: Composition of the TTL over Darwin: local mixing or long-range transport?, Atmos. Chem. Phys., 9, 77257736, doi:10.5194/acp-9-7725-2009, 2009.

Highwood, E. J. and Hoskins, B. J.: The tropical tropopause, Q. J. Roy. Meteorol. Soc., 124, 1579-1604, doi:10.1002/qj.49712454911, 1998.

Holton, J. R., Haynes, P. H., McIntyre, M. E., Douglass, A. R., Rood, R. B., and Pfister, L.: Stratosphere-troposphere exchange, Rev. Geophys., 33, 403-439, doi:10.1029/95RG02097, 1995.

Johnson, B. J., Oltmans, S. J., Vömel, H., Smit, H. G. J., Deshler, T., and Kröger, C.: Electrochemical concentration cell (ECC) ozonesonde pump efficiency measurements and tests on the sensitivity to ozone of buffered and unbuffered ECC sensor cathode solutions, J. Geophys. Res., 107, 4393, doi:10.1029/2001JD000557, 2002.

Kley, D., Crutzen, P. J., Smit, H. G. J., Vomel, H., Oltmans, S. J., Grassl, H., and Ramanathan, V.: Observations of Near-Zero Ozone Concentrations Over the Convective
Pacific: Effects on Air Chemistry, Science, 274, 230-233, doi:10.1126/science.274.5285.230, 1996.

Komhyr, W.: Electrochemical concentration cell for gas analysis, Ann. Geophys., 25, 203-210, 1969.

Komhyr, W., Barnes, R. A., Brothers, G. B., Lathrop, J. A., and Opperman, D. P.: Electrochemical concentration cell ozonesonde performance evaluation during STOIC 1989, J. Geophys. Res., 100, 9231-9244, 1995.

Komhyr, W. D. and Harris, T. B.: Development of an ECC Ozonesonde, NOAA technical report ERL200-APCL 18, US Department of Commerce, National Oceanic and Atmospheric Administration, Environmental Research Laboratories, Boulder, Colorado, 1971.

Lawrence, M. G., Crutzen, P. J., and Rasch, P. J.: Analysis of the CEPEX ozone data using a 3D chemistrymeteorology model, Q. J. Roy. Meteorol. Soc., 125, 2987-3009, doi:10.1002/qj.49712556010, 1999.

Pan, L. L., Paulik, L. C., Honomichl, S. B., Munchak, L. A., Bian, J., Selkirk, H. B., and Vömel, H.: Using transport diagnostics to understand chemistry climate model ozone simulations, J. Geophys. Res., 119, 3586-3599, doi:10.1002/2013JD020558, 2014.

Pan, L. L., Honomichl, S. B., Randel, W. J., Apel, E. C., Atlas, E. L., Beaton, S. P., Bresch, J. F., Hornbrook, R., Kinnison, D. E., Lamarque, J.-F., Saiz-Lopez, A., Salawitch, R. J., and Weinheimer, A. J.: Bimodal distribution of free tropospheric ozone over the tropical western Pacific revealed by airborne measurements, Geophys. Res. Lett., 42, 7844-7851, doi:10.1002/2015GL065562, 2015.

Ploeger, F., Fueglistaler, S., Grooß, J.-U., Günther, G., Konopka, P., Liu, Y., Müller, R., Ravegnani, F., Schiller, C., Ulanovski, A., and Riese, M.: Insight from ozone and water vapour on transport in the tropical tropopause layer (TTL), Atmos. Chem. Phys., 11, 407-419, doi:10.5194/acp-11-407-2011, 2011.

Reid, S. J., Vaughan, G., Marsh, A. R. W., and Smit, H. G. J.: Accuracy of ozonesonde measurements in the troposphere, J. Atmos. Chem., 25, 215-226, doi:10.1007/BF00053792, 1996.

Rex, M., Wohltmann, I., Ridder, T., Lehmann, R., Rosenlof, K. H., Wennberg, P. O., Weisenstein, D., Notholt, J., Krüger, K., Mohr, V., and Tegtmeier, S.: A Tropical West Pacific $\mathrm{OH}$ minimum and implications for stratospheric composition, Atmos. Chem. Phys., 14, 4827-4841, doi:10.5194/acp-14-4827-2014, 2014.

Ridley, B. A., Grahek, F. E., and Walega, J. G.: A small, highsensitivity, medium-response ozone detector for measurements from light aircraft, J. Atmos. Ocean. Tech., 9, 142-148, 1992.

Smit, H. G. J. and the Panel for the assessment of standard operation procedures for ozonesondes (ASOPOS): Quality Assurance and Quality Control for Ozonesonde Measurements in GAW, GAW report 201, World Meteorological Organisation, Geneva, 2013.

Smit, H. G. J. and Sträter, W.: Jülich Ozone Sonde Intercomparison Experiment 2000, GAW report 158, World Meteorological Organisation, Geneva, 2004.

Smit, H. G. J., Sträter, W., Johnson, B. J., Oltmans, S. J., Davies, J., Tarasick, D. W., Hoegger, B., Stubi, R., Schmidlin, F. J., Northam, T., Thompson, A. M., Witte, J. C., Boyd, I., and Posny, F.: Assessment of the performance of ECC-ozonesondes under quasi-flight conditions in the environmental simulation chamber: Insights from the Juelich Ozone Sonde Intercomparison Experiment (JOSIE), J. Geophys. Res., 112, D19306, doi:10.1029/2006JD007308, 2007. 
Solomon, S., Thompson, D. W. J., Portmann, R. W., Oltmans, S. J., and Thompson, A. M.: On the distribution and variability of ozone in the tropical upper troposphere: Implications for tropical deep convection and chemical-dynamical coupling, Geophys. Res. Lett., 32, L23813, doi:10.1029/2005GL024323, 2005.

Takashima, H. and Shiotani, M.: Ozone variation in the tropical tropopause layer as seen from ozonesonde data, J. Geophys. Res., 112, D11123, doi:10.1029/2006JD008322, 2007.

Thompson, A. M.: Southern Hemisphere Additional Ozonesondes (SHADOZ) 1998-2000 tropical ozone climatology 1. Comparison with Total Ozone Mapping Spectrometer (TOMS) and ground-based measurements, J. Geophys. Res., 108, 8238, doi:10.1029/2001JD000967, 2003.

Thornton, D. C. and Niazy, N.: Sources of background current in the ECC ozonesonde: Implications for total ozone measurements, J. Geophys. Res., 87, 8943, doi:10.1029/JC087iC11p08943, 1982.
Thornton, D. C. and Niazy, N.: Effects of solution mass transport on the ECC ozonesonde background current, Geophys. Res. Lett., 10, 97-100, doi:10.1029/GL010i001p00097, 1983.

Vaughan, G., Schiller, C., MacKenzie, A. R., Bower, K., Peter, T., Schlager, H., Harris, N. R. P., and May, P. T.: Studies in a natural laboratory: High-altitude aircraft measurements around deep tropical convection, B. Am. Meteorol. Soc., 89, 647-662, 2008.

Vömel, H. and Diaz, K.: Ozone sonde cell current measurements and implications for observations of near-zero ozone concentrations in the tropical upper troposphere, Atmos. Meas. Tech., 3, 495-505, doi:10.5194/amt-3-495-2010, 2010.

Wang, H. and Mehta, V. M.: Decadal Variability of the Indo-Pacific Warm Pool and Its Association with Atmospheric and Oceanic Variability in the NCEP-NCAR and SODA Reanalyses, J. Climate, 21, 5545-5565, doi:10.1175/2008JCLI2049.1, 2008. 